\title{
DETERMINAN KEPATUHAN WAJIB PAJAK KENDARAAN BERMOTOR DI KOTA SEMARANG
}

\author{
Retno Astuti Ningrum dan Amir Hidayatulloh* \\ Program Studi Akuntansi Fakultas Ekonomi dan Bisnis, Universitas Ahmad Dahlan, Yogyakarta-Indonesia \\ *amir.hidayatulloh@act.uad.ac.id
}

DiPublikasi: 01/01/2020

http://dx.doi.org/10.22225/kr.11.2.1154.190-196

\begin{abstract}
This type of research is quantitative research. The population in this research is a motor vehicle taxpayer. Meanwhile, the sample in this study is a motor vehicle taxpayer in the city of Semarang. The sampling technique in this research used convience sampling. Respondents in this research amounted to 100 respondents. Data collection techniques in research using questionnaires given directly to respondents. Respondents in this study were dominated by male (58 respondents). Whereas female respondents amounted 42 respondents. The analysis techniques in this research used multiple linear regression analysis, with SPSS tools. This study obtained results that perseptions of tax corruption and service quality of tax officers affect taxpayer compliance.
\end{abstract}

Keywords: Taxpayer compliance; perseption on tax corruption; service quality of tax officers

Abstrak

Jenis penelitian ini adalah penelitian kuantitatif. Populasi dalam penelitian adalah wajib pajak kendaraan bermotor. Sedangkan, sampel dalam penelitian ini adalah wajib pajak kendaraan bermotor yang berada di Kota Semarang. Teknik pengambilan sampel dalam penelitian ini menggunakan convenience sampling. Responden dalam penelitian ini berjumlah 100 responden. Teknik pengumpulan data dalam penelitian menggunakan kuesioner yang diberikan langsung kepada responden. Responden dalam penelitian ini didominasi oleh laki-laki ( 58 responden). Sedangkan responden berjenis kelamin perempuan berjumlah 42 responden. Teknik analisis dalam penelitian ini menggunakan analisis regresi linear berganda, dengan alat SPSS. Penelitian ini memperoleh hasil bahwa persepsi korupsi pajak dan kualitas pelayanan petugas pajak berpengaruh terhadap kepatuhan wajib pajak.

Kata Kunci : Kepatuhan wajib pajak; persepsi korupsi pajak; kualitas pelayanan petugas pajak

\section{PENDAhUluan}

Menurut (Undang-undang Nomor 28, 2007), pajak merupakan kontribusi wajib kepada negara yang terutang oleh orang pribadi maupun badan yang bersifat memaksa, tidak mendapatkan jasa timbal balik (imbalan) secara langsung, dan digunakan untuk keperluan Negara bagi sebesarbesarnya kemakmuran rakyat. Sektor perpajakan adalah salah satu sektor yang memberikan andil kepada penerimaan Negara, baik pemerintah pusat maupun pemerintah daerah. Menurut (Undang-Undang Nomor 28, 2009), pajak daerah terdiri dari pajak provinsi dan pajak kabupaten/ kota. Pajak provinsi terdiri dari pajak kendaraan bermotor, bea balik nama kendaraan bermotor, pajak bahan bakar kendaraan bermotor, pajak air permukaan, serta pajak rokok. Sedangkan, pajak kabupaten/kota terdiri dari pajak hotel, pajak restoran, pajak hiburan, pajak reklame, pajak penerangan jalan, pajak mineral bukan logam dan batuan, pajak parkir, pajak air tanah, pajak sarang burung wallet, serta pajak bumi dan bangunan perdesaan dan perkotaan (PBB-P2).

Penerimaan daerah terbesar berasal dari pajak daerah. Dari hasil penerimaan tersebut, pemerintah dapat menggunakannya untuk pembangunan daerah, belanja daerah, serta pengeluaran lain yang digunakan untuk membiayai daerah (Rizqi, 2018). Pada tahun 2017, penerimaan pendapatan asli daerah jawa tengah dari pajak kendaraan bermotor mencapai $40 \%$. Bahkan, sektor perpajakan menjadi sektor yang menyumbang penerimaan pendapatan terbesar (Antoni, 2018).

Kota Semarang merupakan Kota besar yang terletak di jawa tengah yang memiliki puluhan ribu penduduk dengan latar belakang dan tingkat sosial yang berbeda. Masyarakat Kota Semarang memiliki kecenderungan bergaya hidup yang konsumtif. Hal ini ditandai dengan sering bergantinya kendaraan bermotor, namun masyarakat masih memiliki keengganan untuk membayar pajak. Hal ini ditunjukan pada tahun 
2018, persentase kepatuhan wajib pajak di kota Semarang masih kisaran 70 persen yang lebih rendah dibandingkan Yogyakarta, yaitu 92\% (Antoni, 2018); (Linangkung, 2016). Lebih lanjut (Antoni, 2018) menyatakan bahwa selama dua tahun terakhir tingkat penerimaan pajak kendaraan bermotor di kota Semarang selalu dibawah target yang telah ditetapkan.

Faktor yang dapat memengaruhi kepatuhan wajib pajak antara lain persepsi wajib pajak mengenai korupsi pajak (Hehamuhua dalam (Djaja, 2010); (Wibisono \& Kusuma, 2017); (Safitri \& Tambun, 2017), serta pelayanan petugas pajak (Rachmania, Astuti, \& Utami, 2016); (Syah \& Kridiyawati, 2017). Bahkan (Suciaty, Handayani, \& Dwiatmanto, 2014) menyatakan bahwa pemberitaan mengenai korupsi pajak dimedia massa merupakan variabel yang paling dominan terhadap kepatuhan wajib pajak. Namun, beberapa penelitian terdahulu juga memperoleh hasil bahwa kepatuhan wajib pajak tidak dipengaruhi oleh persepsi wajib pajak mengenai korupsi (Sumirat, 2017); (Ulfah, 2018), serta tidak juga dipengaruhi oleh pelayanan petugas pajak (Susanto, 2013); (Ester, Nangoi, \& Alexander, 2017). Oleh karena itu, dari ketidakkonsistenan hasil penelitian terdahulu, maka peneliti termotivasi untuk menguji kembali variabel persepsi wajib pajak mengenai korupsi pajak dan pelayanan petugas pajak terhadap kepatuhan wajib pajak kendaraan bermotor di Kota Semarang.

\section{TINJAUAN PUSTAKA}

Pajak daerah adalah kontribusi wajib kepada daerah yang terutang oleh orang pribadi atau badan yang pemungutannya didasarkan pada undang-undang, tidak mendapatkan imbalan secara langsung, dan hasil pemungutanya digunakan untuk pengeluaran daerah bagi sebesar -besarnya kemakmuran rakyat (Undang-Undang Nomor 28, 2009). Pajak daerah dibedakan menjadi dua yaitu pajak provinsi dan pajak kabupaten/kota. Pajak provinsi meliputi pajak kendaraan bermotor, bea balik nama kendaraan bermotor, pajak bahan bakar kendaraan bermotor, pajak air permukaan, dan pajak rokok. Sedangkan, pajak kabupaten/kota terdiri dari pajak hotel, pajak restoran, pajak hiburan, pajak reklame, pajak penerangan jalan, pajak mineral bukan logam dan batuan, pajak parkir, pajak air tanah, pajak burung wallet, serta pajak bumi dan bangunan perdesaan dan perkotaan (Undang-
Undang Nomor 28, 2009).

Pajak kendaraan bermotor merupakan salah satu jenis pajak provinsi. Pajak kendaraan bermotor didefinisikan sebagai pajak atas kepemilikan dan penguasaan kendaraan bermotor. Kendaraan bermotor adalah semua kendaraan beroda beserta gandengannya yang digunakan di semua jenis jalan darat, dan digerakan oleh peralatan teknik berupa motor serta peralatan lainnya. Motor dan peralatan lain tesebut berfungsi untuk mengubah suatu sumber daya energi tertentu menjadi tenaga gerak kendaraan bermotor yang bersangkutan, termasuk alat-alat berat dan alat-alat besar yang dalam pengoperasinya menggunakan roda dan motor tidak melekat secara permanen serta kendaraan bermotor yang dioperasikan di air (Peraturan Gubernur Jawa Tengah Nomor 23, 2015).

Lebih lanjut (Peraturan Gubernur Jawa Tengah Nomor 23, 2015) membagi tarif pajak kendaraan bermotor menjadi empat golongan. Golongan pertama adalah 1,5 persen untuk kepemilikan pertama kendaraan bermotor pribadi atau badan. Golongan kedua adalah satu persen untuk kendaraan bermotor angkutan umum. Golongan ketiga 0,5 persen untuk kendaraan ambulans, pemadam kebakaran, lembaga sosial keagamaan, dan instansi pemerintah. Sedangkan, golongan keempat yaitu 0,2 persen untuk kendaraan bermotor alat-alat berat dan alat-alat besar. Besarnya tarif progresif yang ditetapkan dibedakan menjadi beberapa kepemilikan, yaitu kepemilikan kedua 2 persen, kepemilikan ketiga 2,5 persen, kepemilikan keempat 3 persen, serta kepemilikan kelima dan seterusnya adalah 3,5 persen.

Persepsi adalah penginderaan, stimultan individu melalui alat indera yang dinterprestasikan, sehingga mudah dipahami dan dimengerti tentang apa yang diterima. Proses menginterprestasikan stimultan dipengaruhi oleh pengalaman dan proses yang dialami oleh masing -masing individu (Khairani, 2013). Sedangkan, tindak pidana adalah ketika seseorang melawan hukum dengan melakukan perbuatan yang bertujuan untuk memperkaya diri sendiri atau orang lain atau suatu korporasi yang dapat merugikan keuangan Negara atau perekonomian Negara, dipidana penjara paling singkat empat tahun dan paling lama dua puluh tahun dan denda paling sedikir Rp200.000.000 serta paling banyak Rp1.000.000.000 (Undang-Undang Nomor 20, 2001). Bahkan Mulan dalam (Muhammad \& 
Poernomo, 2005) menyatakan bahwa seorang pejabat pemerintah dapat dikatakan korupsi jika pejabat tersebut menerima atau memberikan uang sebagai upaya untuk melakukan sesuatu yang sebenarnya tidak diperbolehkan dilakukan selama menjalankan tugas. Sehingga, persepsi korupsi pajak didefinisikan sebagai interprestasi dan pandangan wajib pajak dalam mengartikan kasus korupsi pajak di Indonesia (Rachmania et al., 2016).

Menurut (Menteri Pendayagunaan Aparatur Negara: 63/KEP/M.PAN/7, 2003), pelayanan publik merupakan kegiatan pelayanan yang dilakukan oleh penyelenggaran pelayanan publik sebagai upaya pemenuhan kebutuhan penerimaan pelayanan maupun pelaksanaan ketentuan peraturan perundang-undangan. Standar pelayanan publik harus memiliki jaminan adanya kepastian bagi penerima pelayanan. Standar pelayanan merupakan suatu ukuran dalam penyelenggaraan pelayanan publik yang wajib ditaati oleh pemberi maupun penerima pelayanan. Pengukuran kualitas layanan tidak hanya diukur oleh pihak yang melayani, akan tetapi juga oleh pihak yang dilayani. Kualitas layanan diukur berdasarkan enam variabel, yaitu kemampuan, sikap, penampilan, perhatian, tindakan, dan tanggungjawab.

Kemampuan adalah pengetahuan atau keterampilan yang wajib diperlukan untuk melaksanakan suatu program layanan prima seperti berkomunikasi secara efektif. Sikap adalah perilaku saat menghadapi pelanggan. Penampilan adalah penampilan individu baik secara fisik maupun non fisik yang memberikan kepercayaan diri dan kredibilitas dari pihak lain. Perhatian adalah kepedulian pada pelanggan berupa perhatian akan kebutuhan maupun pemahaman atas saran dan kritik. Tindakan merupakan sesuatu yang dilakukan secara nyata untuk memberikan layanan kepada pelanggan. Serta, tanggung jawab adalah sikap keberpihakan kepada pelanggan sebagai wujud keberpihakan untuk meminimalisir ketidakpuasan pelanggan (Barata, 2004).

Kepatuhan wajib pajak adalah ketersediaan wajib pajak untuk tunduk dan patuh dalam melaksanakan kewajiban perpajakannya yang sesuai dengan peraturan perundang-undangan perpajakan. Kepatuhan wajib pajak dibedakan menjadi kepatuhan formal dan kepatuhan materiil. Kepatuhan formal merupakan keadaan dimana wajib pajak memenuhi kewajiban formal yang sesuai dengan ketentuan undang-undang perpajakan. Sedangkan, kepatuhan materiil adalah suatu keadaan dimana wajib pajak secara substantive memenuhi semua ketentuan material perpajakan yaitu sesuai dengan isi dan jiwa undang-undang perpajakan. Isi dari kepatuhan materill juga meliputi kapatuhan formal (Rahayu, 2013).

Wajib pajak dikatakan patuh ketika memenuhi persyaratan yaitu (1) tepat waktu dalam menyampaikan surat pemberitahuan, (2) tidak memiliki tunggakan pajak untuk semua jenis pajak, kecuali tunggakan pajak yang telah memperoleh izin mengangsur atau menunda pembayaran pajak, (3) laporan keuangan diaudit oleh akuntan publik atau lembaga pengawasan keuangan pemerintah dengan pendapat wajar tanpa pengecualian selama tiga tahun berturutturut, serta (4) tidak pernah dipidana karena melakukan pidana pada bidang perpajakan berdasarkan putusan pengadilan yang mempunyai kekuatan hukum tetap dalam jangka waktu lima tahun terakhir (Keputusan Menteri Keuangan Nomor 544/KMK.04, 2000).

Berdasarkan uraian sebelumnya, maka rerangka penelitian ini adalah sebagai berikut:

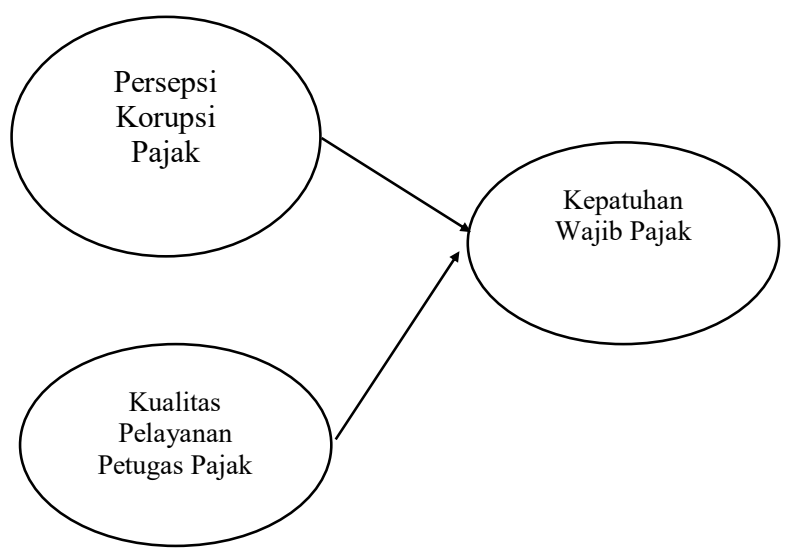

Gambar 1

Kerangka Penelitian

\section{Pengaruh Persepsi Korupsi Pajak Terhadap Kepatuhan Wajib Pajak}

Persepsi merupakan asumsi atau pemikiran yang didasarkan pada berita maupun pengalaman. Banyaknya kasus mengenai korupsi di Indonesia membuat wajib pajak merasa khawatir untuk membayar pajak dan berpangaruh terhadap kepatuhan wajib pajak. Sehingga, semakin banyak kasus korupsi pajak yang dilakukan oleh petugas pajak, maka semakin kuat persepsi yang timbul pada diri wajib pajak bahwa uang yang 


\begin{abstract}
dibayarkan atau disetorkan kepada Negara tidak digunakan sebagaimana mestinya, sehingga terjadi ketidakpercayaan wajib pajak kepada petugas pajak. Hal ini akan berpengaruh pada kepatuhan wajib pajak (Rachmania et al., 2016). Atau dengan kata lain, semakin banyak pejabat yang korupsi maka membuat wajib pajak tidak percaya untuk membayar pajak, sehingga wajib pajak berupaya tidak patuh dalam membayar pajak. Pernyataan ini didukung oleh hasil penelitian Hehamuhua dalam (Djaja, 2010); (Wibisono \& Kusuma, 2017); (Safitri \& Tambun, 2017) yang menyatakan bahwa persepsi korupsi pajak berpengaruh terhadap kepatuhan wajib pajak. Oleh karena itu, hipotesis pertama penelitian ini adalah sebagai berikut:
\end{abstract}

$\mathrm{H}_{1}$ : Persepsi korupsi pajak berpengaruh terhadap kepatuhan wajib pajak

\section{Pengaruh Kualitas Pelayanan Petugas Pajak Terhadap Kepatuhan Wajib Pajak}

Kualitas pelayanan petugas pajak merupakan salah satu faktor yang memengaruhi kepatuhan wajib pajak. Hal ini seperti yang diungkapkan oleh (Rachmania et al., 2016), ketika wajib pajak mendapatkan pelayanan yang baik dari fiskus, maka menumbuhkan rasa puas pada diri wajib pajak. Sehingga, semakin wajib pajak merasa puas maka wajib pajak akan patuh terhadap peraturan perpajakan. Pernyataan ini didukung oleh (Suciaty et al., 2014); (Syah \& Kridiyawati, 2017), kualitas pelayanan petugas pajak berpengaruh terhadap kepatuhan wajib pajak. Oleh karena itu, hipotesis kedua penelitian ini adalah sebagai berikut:

$\mathrm{H}_{2}$ : Kualitas pelayanan petugas pajak berpengaruh terhadap kepatuhan wajib pajak

\section{METODE}

Jenis data yang digunakan dalam penelitian ini adalah data kuantitatif. Populasi dalam penelitian ini adalah wajib pajak kendaraan bermotor. Sedangkan, sampel dalam penelitian ini adalah wajib pajak kendaraan bermotor di Kota Semarang. Teknik pengambilan sampel dalam penelitian ini menggunakan convience sampling. Variabel dalam penelitian ini terdiri dari variabel dependen (kepatuhan wajib pajak), dan variabel independen (persepsi korupsi pajak dan kualitas pelayanan petugas pajak). Definisi operasional dan pengukuran masing-masing variabel disajikan pada tabel 1. Pengumpulan data dalam penelitian ini menggunakan kuesioner yang secara langsung diberikan kepada responden. Teknik analisis data dalam penelitian menggunakan analisis regresi linear berganda.

Tabel 1

Definsi Operasional dan Pengukuran Variabel

\begin{tabular}{|c|c|c|c|c|}
\hline Variabel & Definisi & Referensi & Pengukuran & Referensi \\
\hline $\begin{array}{l}\text { Kepatuhan wajib } \\
\text { pajak }\end{array}$ & $\begin{array}{l}\text { Kesediaan wajib pajak } \\
\text { untuk tunduk dan } \\
\text { patuh dalam } \\
\text { melaksanakan } \\
\text { kewajiban } \\
\text { perpajakannya } \\
\text { berdasarkan peraturan } \\
\text { perundang-undangan } \\
\text { perpajakan. }\end{array}$ & (Rahayu, 2013) & $\begin{array}{l}\text { Lima item pertanyaan } \\
\text { yang diukur dengan } \\
\text { menggunakan skala } \\
\text { likert lima poin. }\end{array}$ & $\underset{\text { 2016) }}{\text { (Rachmania et al., }}$ \\
\hline $\begin{array}{l}\text { Persepsi korupsi } \\
\text { pajak }\end{array}$ & $\begin{array}{c}\text { Interprestasi dan } \\
\text { pandangan wajib pajak } \\
\text { dalam mengartikan } \\
\text { kasus korupsi pajak di } \\
\text { Indonesia. }\end{array}$ & $\begin{array}{l}\text { (Rachmania et } \\
\text { al., 2016) }\end{array}$ & $\begin{array}{l}\text { Delapan item } \\
\text { pertanyaan yang } \\
\text { diukur dengan } \\
\text { menggunakan skala } \\
\text { likert lima poin. }\end{array}$ & $\begin{array}{c}\text { (Rachmania et al., } \\
\text { 2016) }\end{array}$ \\
\hline $\begin{array}{l}\text { Kualitas pelayanan } \\
\text { petugas pajak }\end{array}$ & $\begin{array}{l}\text { Ukuran atau nilai atas } \\
\text { kegiatan fiskus dalam } \\
\text { memberikan pelayanan } \\
\text { untuk memenuhi } \\
\text { kebutuhan wajib pajak } \\
\text { dalam rangka } \\
\text { pemenuhan kewajiban } \\
\text { perpajakannya. }\end{array}$ & $\begin{array}{c}\text { (Rachmania et } \\
\text { al., 2016) }\end{array}$ & $\begin{array}{c}\text { Sebelas item } \\
\text { pertanyaan yang } \\
\text { diukur dengan } \\
\text { menggunakan skala } \\
\text { likert lima poin. }\end{array}$ & $\underset{\text { 2016) }}{\text { (Rachmania et al., }}$ \\
\hline
\end{tabular}




\section{HASIL DAN PEMBAHASAN}

Data dalam penelitian ini diperoleh melalui penyebaran kuesioner secara langsung kepada 105 responden. Dari 105 kuesioner yang disebarkan sebanyak 105 kuesioner dikembalikan oleh responden, akan tetapi sebanyak 5 kuesioner tidak dapat digunakan. Hal ini karena responden menjawab tidak secara lengkap, dan terdapat jawaban ganda dari responden pada item pertanyaan. Oleh karena itu, kuesioner yang dapat dilakukan pengolahan lebih lanjut adalah 100 kueisoner. Berikut adalah ringkasan pengiriman dan pengembalian kuesioner yang disajikan pada tabel 2 .

Tabel 2

Ringkasan Pengiriman dan Pengembalian Kuesioner

\begin{tabular}{cc}
\hline Keterangan & Jumlah kuesioner \\
\hline Kuesioner yang dikirim & 105 \\
Kuesioner yang dikembalikan & 105 \\
Kuesioner yang tidak digunakan & 5 \\
Kuesioner yang digunakan & 100 \\
\hline
\end{tabular}

Sumber: data primer, diolah (2019).

pendidikan, jenis pekerjaan, pendapatan, jenis

Deskripsi responden dalam penelitian ini meliputi jenis kelamin, usia responden, tingkat

kendaraan, dan lama kepemilikan kendaraan. Deskripsi responden disajikan pada tabel 3.

Tabel 3

Deskripsi Responden

\begin{tabular}{|c|c|c|}
\hline \multicolumn{2}{|c|}{ Keterangan } & \multirow{2}{*}{$\frac{\text { Frekuensi }}{58}$} \\
\hline Jenis Kelamin & Laki-Laki & \\
\hline & Perempuan & 42 \\
\hline \multirow[t]{3}{*}{ Usia } & Kurang dari 25 tahun & 18 \\
\hline & $25-45$ tahun & 70 \\
\hline & Lebih dari 45 tahun & 12 \\
\hline \multirow[t]{5}{*}{ Tingkat Pendidikan } & SMP & 4 \\
\hline & SMA & 48 \\
\hline & Diploma & 20 \\
\hline & S1 & 20 \\
\hline & $\mathrm{S} 2 / \mathrm{S} 3$ & 8 \\
\hline \multirow[t]{7}{*}{ Jenis Pekerjaan } & Sopir & 8 \\
\hline & Karyawan swasta & 22 \\
\hline & Wiraswasta & 25 \\
\hline & PNS & 20 \\
\hline & Polri/TNI & 5 \\
\hline & Pelajar & 9 \\
\hline & Ibu rumah tangga & 11 \\
\hline \multirow[t]{4}{*}{ Pendapatan Per Tahun } & Kurang dari Rp25.000.000 & 65 \\
\hline & Rp25.000.000-Rp50.000.000 & 28 \\
\hline & Rp50.000.000-Rp75.000.000 & 5 \\
\hline & Lebih dari Rp100.000.000 & 2 \\
\hline \multirow[t]{2}{*}{ Jenis Kendaraan } & Roda dua & 63 \\
\hline & Roda empat & 37 \\
\hline \multirow[t]{4}{*}{ Lama Kepemilikan Kendaraan } & Kurang dari 5 tahun & 33 \\
\hline & 5-10 tahun & 40 \\
\hline & 11-25 tahun & 20 \\
\hline & Lebih dari 25 tahun & 7 \\
\hline
\end{tabular}

Sumber: data primer, diolah (2019)

Tabel 3 menunjukan bahwa responden dalam penelitian ini didominasi oleh responden berjenis kelamin laki-laki (58 responden). Usia responden didominasi oleh usia 25-45 tahun (70 responden). Tingkat pendidikan responden didominasi oleh 
SMA (48 responden). Jenis pekerjaan responden didominasi oleh wiraswasta (25 responden). Pendapatan responden per tahun didominasi oleh kurang dari Rp25.000.000 (65 responden). Jenis kendaraan yang dimiliki oleh responden didominasi oleh roda dua (63 responden). Lama kepemilikan kendaraan didominasi oleh 5-10 tahun (40 responden).

Teknik analisis data dalam penelitian ini menggunakan analisis regresi linear berganda dengan bantuan alat SPPS. Hasil pengujian hipotesis disajikan pada tabel 4.

Tabel 4

Hasil Pengujian Hipotesis

\begin{tabular}{cccc}
\hline Variabel & Beta & Signifikasi & Kesimpulan \\
\hline Konstanta & 7,102 & 0.014 & \\
Persepsi Korupsi Pajak & 0,282 & 0,000 & Terdukung \\
Kualitas Pelayanan Petugas pajak & 0,140 & 0,004 & Terdukung \\
Variabel Dependen & & Kepatuhan Wajib Pajak & \\
F $_{\text {hitung }}$ & & 14,386 & \\
Signifikasi F & & 0,000 & \\
Adjusted R-Square & & 0,213 & \\
\hline
\end{tabular}

Sumber: data primer, diolah (2019)

Tabel 4 menunjukan bahwa penelitian ini memiliki nilai adjusted $R$-Square sebesar 0,213. Hal ini berarti bahwa variabel kepatuhan wajib pajak dapat dijelaskan oleh variabel persepsi korupsi pajak dan kualitas pelayanan petugas pajak sebesar 21,30 persen , dan 78,70 persen dijelaskan oleh variabel lain di luar model. Tabel 4 juga menunjukan bahwa nilai signifikasi uji $F$ $(0,000)$ yang lebih kecil dibandingkan dengan 0,05 . Hal ini bearti minimal ada satu variabel independen (persepsi korupsi pajak dan kualitas pelayanan petugas pajak) yang berpengaruh terhadap kepatuhan wajib pajak.

Tabel 4 menunjukan bahwa persepsi korupsi pajak berpengaruh terhadap kepatuhan wajib pajak. Hal ini ditunjukan dengan nilai signifikasi $(0,000)$ yang lebih kecil dibandingkan dengan 0,05 . Atau dengan kata lain, hipotesis pertama $\left(\mathrm{H}_{1}\right)$ penelitian ini terdukung. Hal ini berarti bahwa semakin banyak pejabat yang korupsi maka membuat wajib pajak tidak percaya untuk membayar pajak. Sehingga, wajib pajak berupaya untuk menghindari pajak dan sebaliknya. Semakin sedikit pejabat yang tidak korupsi, maka kepercayaan wajib pajak untuk membayar pajak meningkat. Sehingga, wajib pajak berupaya untuk patuh dalam membayar pajak. Hasil ini mengkonfirmasi pernyataan sebelumnya, yaitu (Djaja, 2010); (Wibisono \& Kusuma, 2017); (Safitri \& Tambun, 2017) yang menyatakan salah satu faktor yang memengaruhi kepatuhan wajib pajak adalah persepsi korupsi pajak.

Selain persepsi korupsi pajak, faktor lain yang memengaruhi kepatuhan wajib pajak adalah kualitas pelayanan petugas pajak. Hal ini ditunjukan dengan nilai signifikasi $(0,004)$ yang disajikan pada tabel 4 lebih kecil dibandingkan dengan 0,05. Atau dengan kata lain, hipotesis kedua $\left(\mathrm{H}_{2}\right)$ penelitian ini terdukung. Hal ini berarti bahwa ketika fiskus memberikan pelayanan yang baik kepada wajib pajak, maka wajib pajak akan merasa puas. Sehingga, semakin wajib pajak puas atas pelayanan petugas pajak maka wajib pajak akan patuh untuk membayar pajak. Hasil penelitian ini mengkonfirmasi pernyataan sebelumnya yaitu (Suciaty et al., 2014); (Syah \& Kridiyawati, 2017) yang menyatakan bahwa kualitas pelayanan petugas pajak berpengaruh terhadap kepatuhan wajib pajak.

\section{SIMPULAN}

Kepatuhan wajib pajak kendaraan bermotor dipengaruhi oleh persepsi korupsi pajak dan kualitas pelayanan petugas pajak. Sehingga, dari hasil penelitian ini diharapkan pemerintah atau fiskus dapat menjaga kepercayaan wajib pajak, salah satunya dengan tidak melakukan korupsi. Selain itu, diharapkan pihak fiskus atau petugas pajak dapat memberikan pelayanan yang baik kepada wajib pajak. Hal ini karena kualitas pelayanan dari petugas pajak dapat mendorong wajib pajak untuk patuh dalam membayar pajak.

Penelitian ini tidak terlepas dari sebuah keterbatasan. Nilai adjusted $R$-Square dalam penelitian ini adalah 21,30 persen, yang berarti bahwa variabel persepsi korupsi pajak dan kualitas pelayanan petugas pajak dapat menjelaskan variabel kepatuhan wajib pajak sebesar 21,30 persen. Sehingga, 78,70 persen variabel kepatuhan wajib pajak dijelaskan oleh 
variabel lain di luar model. Sehingga, penelitian selanjutnya dapat menambahkan variabel independen, seperti sanksi pajak.

\section{DAFTAR PUSTAKA}

Antoni, A. (2018). Kepatuhan Bayar Pajak Warga Semarang Baru 70\%. Ekbis.Sindonews.Com. Retrieved from https://ekbis.sindonews.com/read/1289461/33/ kepatuhan-membayar-pajak-warga-semarang-baru70-1520962246

Barata, A. A. (2004). Dasar-Dasar Pelayanan Prima. Jakarta: PT Elex Media Komputindo.

Djaja, E. (2010). Meredesain Pengendalian Tindak Pidana Korupsi. Jakarta: Sinar Grafika.

Ester, K. G., Nangoi, G. B., \& Alexander, S. W. (2017). Pengaruh Kualitas Pelayanan Pajak dan Pengetahuan Wajib Pajak terhadap Kepatuhan Wajib Pajak Orang Pribadi di Kelurahan Kleak Kecamatan Malalayang Kota Malang. Jurnal Riset Akuntansi Going Concern, 12(2), 523-530.

Keputusan Menteri Keuangan Nomor 544/KMK.04. (2000). Tentang Kriteria Wajib Pajak Yang Dapat Diberikan Pengembalian Pendahuluan Kelebihan Pembayaran Pajak.

Khairani, M. (2013). Psikologi (Psikologi Umum). Yogyakarta: Aswan Pressindo.

Linangkung, E. (2016, April 28). Kepatuhan Wajib Pajak DIY capai 92\%. Ekbis.Sindonews.Com. Retrieved from https://ekbis.sindonews.com/read/1200843/33/ kepatuhan-wajib-pajak-diy-capai-92-1493345445

Menteri Pendayagunaan Aparatur Negara: 63/KEP/ M.PAN/7. (2003). Tentang Pedoman Umum Penyelenggaran Pelayanan Publik.

Muhammad, F., \& Poernomo, B. (2005). Korupsi Dalam Praktik Bisnis. Jakarta: PT Gramedia Pustaka Utama.

Peraturan Gubernur Jawa Tengah Nomor 23. (2015). Tentang Penghitungan Dasar Pengenaan Pajak Kendaraan Bermotor dan Bea Balik Nama Kendaraan Bemotor Pembuatan Sebelum Tahun 2015.

Rachmania, F. M., Astuti, E. S., \& Utami, H. N. (2016). Pengaruh Persepsi Korupsi Pajak Dan Kualitas Pelayanan Fiskus Terhadap Kepatuhan Wajib Pajak (Studi Pada Wajib Pajak Orang pribadi Yang Terdaftar di KPP Pratama Batu). Jurnal Mahasiswa Perpajakan, 10(1), 1-8.

Rahayu, S. K. (2013). Perpajakan Indonesia: Konsep dan Aspek Formal. Yogyakarta: Graha Ilmu.

Rizqi, A. N. (2018). Pemprov Jateng Targetkan PAD 2018 Rp 12,9 Triliun. Jatengpos.Com. Retrieved from https://jatengpos.com/read/20180220/78/740795/ jateng-targetkan-pad-2018-capai-rp129-triliun

Safitri, D., \& Tambun, S. (2017). Pengaruh Kesadaran Wajib Pajak dan Persepsi Korupsi Pajak Terhadap Kepatuhan Wajib Pajak Dengan Kepercayaan Masyarakat Sebagai Variabel Moderating. Jurnal Unversitas 17 Agustus 1945, 2(2), 23-33.

Suciaty, Handayani, S. R., \& Dwiatmanto. (2014). Persepsi Wajib Pajak Mengenai Korupsi Pajak dan Pengaruhnya Terhadap Kepatuhan Wajib Pajak (Studi Pada WPOP Yang Menjalankan Usaha di KPP
Pratama Malang Utara). Jurnal E-Perpajakn, 1(1), 23 -33 .

Sumirat, S. (2017). Pengaruh Persepsi Korupsi Pajak, Kualitas Pelayanan, Pengetahuan Perpajakan dan Sanksi Pajak Terhadap Kepatuhan Wajib Pajak (Studi Pada Wajib Pajak Orang Pribadi Yang Terdaftar di KPP Kota Yogyakarta) (Universitas Islam Indonesia). Retrieved from https:// dspace.uii.ac.id/handle/123456789/4486

Susanto, J. N. (2013). Pengaruh Persepsi Pelayanan Aparat Pajak, Persepsi Pengetahuan Wajib Pajak, dan Persepsi Pengetahuan Korupsi Terhadap Kepatuhan: Kajian Empiris Pada Wajib Pajak Orang Pribadi Yang Memiliki Usaha di Kota Probolinggo Kecamatan Mayangan. Jurnal Ilmiah Mahasiswa Universitas Surabaya, 2(1), 1-17.

Syah, A., \& Kridiyawati. (2017). Analisis Faktor-Faktor Yang Mempengaruhi Kepatuhan Wajib Pajak Dalam Membayar Pajak Kendaraan Bermotor. Jurnal AKSI (Akuntansi Dan Sistem Informasi), 2(1), 65-77.

Ulfah, S. (2018). Pengaruh Persepsi Korupsi Pajak, Kualitas Pelayanan, Pengetahuan Perpajakan, Sanski Pajak, dan Religiusitas Terhadap Kepatuhan Wajib Pajak (Universitas Islam Indonesia). Retrieved from https:// dspace.uii.ac.id/handle/123456789/6114

Undang-Undang Nomor 20. (2001). Tentang Pemberantasan Tindakan Korupsi.

Undang-undang Nomor 28. (2007). Tentang Ketentuan Umum dan Tata Cara Perpajakan.

Undang-Undang Nomor 28. (2009). Tentang Pajak Daerah dan Retribusi Daerah.

Wibisono, A., \& Kusuma, Y. (2017). Analisis Faktor-Faktor Yang Mempengaruhi Kepatuhan Wajib Pajak Dalam Membayar Pajak Kendaraan Bermotor. Jurnal Riset Manajemen, 4(2), 169-180. 